Arch. Tierz., Dummerstorf 42 (1999) 1, 57-66

University of Agricultural Sciences, Institute of Animal Husbandry, Gødøllర, Hungary

MIHÁLY WITTMANN and JÁNOS DOHY

\title{
On some possibilities and prospects of gene conservation and utilisation of pig breeds
}

Dedicated to Prof. Dr. Dr. h.c. Gottfried Leuthold on the occasion of his $65^{\text {th }}$ birthday

\begin{abstract}
Summary
Nowadays, there are 47 rare pig breeds in the world the majority of which in Europe. Disappeared breeds are considered to be 139 breeds (mostly in Europe). The prevention of further losses of needs needs special measurements and methods for maintenance and conservation of genetic values. In spite of a lot of means being available, the conservation programs use the possibilities only moderately. Besides the commonly used testing results, special genetic analysis should be practised and extended widely, including blood groups, enzyme and other protein polymorphisms and the new results of genom analysis (marker genes atc.). A proper - and well identified - genetic make up is of minimal precondition for preparing effective mating plans to avoid and reduce inbreeding rate in closed populations. Besides number of traits and markers, more emphasis should be given to the distribution of the genetic markers on each chromosomes detected. If a chromosome were controlled (detected by at least 5 loci, thre would be round 200 parameters necessary as a minimum for a porper control fo the genomic background of a breed. Whilst it is very diffucult to prevent gene losses in small populations (small effective population size) for long term, reconstruction of them should be comined with cryopreservational and up-to-date DNA-screening.
\end{abstract}

Key words: pig, gene conservation, genetic resources, rare breeds

\section{Zusammenfassung}

Titel der Arbeit: Einige Möglichkeiten und Vorstellungen der Genkonservierung zur Erhaltung von Schweinerassen

Es gibt 47 seltene Schweinerassen in der Welt, die Mehrheit davon sind in Europa aufzufinden. Die Anzahl der verschwundenen Rassen wird auf 139 geschätzt (hauptsächlich in Europa). Um die weiteren Verluste an Rassen zu verhindern und den genetischen Wert aufrechterhalten bzw. konservieren zu können, müssen spezielle $\mathrm{MaBnahmen}$ und Methoden angewendet werden. Obwohl für diesen Zweck verschiedene Mittel zur Verfügung stehen, werden diese ungenügend genutzt. Für diesen Zweck sind spezielle genetische Analysen anzuwenden, wie z.B. die Bestimmung der Blutgruppen, der Enzym- und anderen Proteinpolymorphismen oder die neuesten Ergebnisse der Genomanalyse (Markergene). Diese gute genetische Identifikation ist die minimale Voraussetzung für Paarungspläne um eine hohe Inzucht in geschlossenen Populationen vermeiden zu können. Neben einer Vielzahl von Merkmalen und Markern muß die Verteilung der genetischen Marker auf den ausgewiesenen Chromosomen bekannt sein. Wenn ein Chromosom auf min. 5 Loci analysiert und kontrolliert wird, müßten mindestens ca. 200 Parameter kontrolliert werden, um den genetischen Hintergrund einer Rasse richtig bestimmen zu können. Obwohl die langfristige Verhinderung der Genverluste in kleinen (kleinste effektivste Populationsgröße) Populationen äußerst schwierig ist, sollte ihre Rekonstruktion mit Hilfe von Kryokonserveinung und modernem DNA-screening kombiniert werden.

Schlüsselwörter: Schwein, Genkonservierung, Genreserve, seltene Schweinerassen 
Exchange of ideas and co-operation with German scientists in the field of applied animal genetics and breeding has been practised in Hungary for a long time. So, Professor GOTTFRIED LEUTHOLD was one of the most prominent co-authors of the international handbook: "Actual Questions of Applications of Genetics in Animal Breeding" edited by János Dohy, published in 1978 in Budapest, and in 1982 in Sofia and in Moscow, as well. In this team-work f.i. the actual situation and prospects of the biochemical genetics and the possibilities future tasks of gene-conservation and utilisation of international animal genetic resources were elaborated and emphasised. Ever since - in the last twenty years - the international collaboration and integration has been extended and intensified. In this article, we intend to give a comprehensive short overview concerning actual aspects and prospects of the conservation and co-ordinated utilisation of gene-resources of pig breeds in order to enhance the fruitful international co-operation in animal breeding.

\section{Introduction}

This century, especially the last fifty years changed extremely the structure of pig breeds all over the world. Hundreds of pig breeds disappeared because they were not competitive with modern and intensive breeds. During this century pig breeders' attention has been focussed on limited number of breeds because of their specific combination ability in crossings or special traits being important for production. Other breeds such as local, native and indigenous breeds were assimilated to more productive breeds used for crossing over or breeders gave up their breeding and maintaining because of changes in consumer preference (more meat, better eating quality etc.). By the end of the last century a lot of pig breeds became endangered and after short agony they vanished finally. Only in Hungary five native breeds disappeared at the turn of century. This process is being continued and endangered more and more breeds all over the world.

In Europe alone, 60 breeds of livestock have become extinct this century and further 200 are considered to be endangered (MAIJALA et al., 1994). Besides extinction of breeds, genes are also disappearing as a consequence of strong pressure of selection on limited number of traits in small populations and by mating of relative animals. Only in the last 20 years the world realised the danger of diversity decreasing continuously. Consciousness of importance of genetic diversity started the process of conservation of rare breeds in all species and the short past was the final deadline for last refuge and avoiding the total loss of their genetic resources and cultural value. Other breeds having larger population are also shifting toward the danger zone of survival. Modern times might easily waste diversity created by the nature during more thousand years.

Populations which are not endangered can survive without genetic drift provided their size is large enough. The endangered status of a breed can be expressed by the number of breeding females, sex ratio or by effective population size.

Endangered status (BODÓ et al., 1984) implies that effective size of the population is not enough to avoid inbreeding and therefore spontaneous or other genetic losses of the breed is in danger of extinction. 
Critical status is an extended endangered status and indicates that the population is close to extinction. In this stage the genetic variation is regularly reduced and the breed can not be considered as an original one (BODÓ et al., 1984).

In each case the population should be preserved by proper breeding method.

In spite of the fact that old, native and historical breeds can not play any role in the international commercial production they have special allele combinations which may very useful to pig breeding in the future. On the other hand such a breed is often culturally highly evaluated heritage of a nation and for this reason worth conserving it and in this manner its cultural and scientific interest contributes to maintenance of biological diversity of the nature, too. Rare breeds with special traits and producing non-conventional products enrich and enlarge the food market helping the conservation of themselves.

What are the reasons for which a population should be preserve?

\section{Genetic value}

The genetic merit from a breed to be preserved [according to BODÓ (1990)]:

valuable traits:

adaptability performance,

resistance,

other traits,

purity,

distinctiveness,

complementarity.

\section{Scientific use}

Preserved populations may play role as control populations for selected stocks. Research needs populations to study valuable potentials of breeds, such as: resistance, adaptation ability, exhibition and isolation of special genes etc.

\section{Cultural interest}

Many breeds in a country or a region have a long and special history and are stored up deeply in the soul of people. There are many breeds which are worth conserving for their beauty and aesthetic value or unique exterior which may have equal value to other cultural properties. Ancient breeds are in centre of tourism and educational interest, too.

\section{Main objectives for breed conservation}

According to the FAO (1992) directives conserving animal resources is based on two concepts: conservation of "genes" and conservation of "breeds" or populations. This means to ensure the survival of individual with genetically controlled characteristics inherent within a population and for a breed: characteristics that it exhibits. 
Almost each country in the world has trouble with conservation of historical pig breeds. According to an overview of breeds, types and varieties (MASON, 1988) the total number of population disappeared across the world was 139 and 114 from them in Europe. The majority of rare breeds (39 from 47) are located also in Europe. (Table 1.)

Table 1

An overview of pig breeds, types and varieties across the world (from MASON, 1988) (Überblick der Schweinerassen, Typen und Variationen auf der Welt)

\begin{tabular}{lcrrrrr}
\hline $\begin{array}{l}\text { Status } \\
\text { of breed }\end{array}$ & Africa & America & Asia & Europe & Oceania & Total \\
\hline Important & 1 & 11 & 15 & 44 & - & 71 \\
Secondary & 6 & 40 & 130 & 77 & 4 & 257 \\
Rare & - & 5 & 2 & 39 & 1 & 47 \\
Extinct & - & 16 & 8 & 114 & 1 & 139 \\
\hline Total & 7 & 72 & 155 & 274 & 6 & 514 \\
\hline
\end{tabular}

In recent years the number of blood lines of original English breeds has decreased in UK (ARK, 1993) and importation of rare lines from Australia is a way of resolution in maintenance of them.

Although the Iberian pig is of a rather large population in Spain and due to the good market of its characteristic products, the population is still increasing but because of extended crossbreeding, some variations of the breed are endangered (RODRIGANEZ et al., 1993)

The Polish Pulawska breed decreased from 610 to 197 sows during the last decade and reached the margin of critical status, in spite of relative good production traits: growth rate $750 \mathrm{~g}$; back fat: $22 \mathrm{~mm}$; meat: $51,5 \%$ and 10,5 piglets at weaning (WALKIEWICZ et al. 1997). Polish Zlotnicka White and Zlotnicka Spotted are endangered.

Croatia is intending to save the Turopolje breed in frame of an international project. The breed was especially damaged during the last Yugoslavian war. A rescue plan was set up and new breeding units were established inside and outside the country (GRUNENFELDER, 1994, 1995). Black Slavonian breed belongs to endangered breeds, too. (CAPUT, 1995; UREMOVIC, 1995)

Slovenia has also an own original breed: the Krskopolje pig (SALEHAR, 1994). Conservation of it started in 1993 with very small number of animals. Detailed research programs financed by the government should detect all aspects for effective preservation.

In Middle-European area the Mangalica breed has a long history and it is bred in several countries. In Hungary three genetic varieties exist: blond, red and swallowbellied. All they are in critical status. Due to the small populations conservation is rather complicated and it is possible only by international co-operation. Characteristic to these breeds is that they are genetically clear and homozygote in numerous traits.

The Bazna pig in Romania which is originating from crossings of Mangalica and Berkshire round 100 years ago, has a population of more than 70 thousand animals. In spite of the substantial population size some local types of the breed are endangered 
(BACHIVANGI and STANCIU, 1998).

Mangalica was wide-spreaded swine breed in the Balkan area in the past but nowadays it makes only a small population in Yugoslavia. Other important ancient breed in Yugoslavia is the Moravka being formed out from crossing of Sumadian and Berkshire breeds (SARAC et al., 1998).

According to the current situation in Portugal, state policy influenced positively the maintenance of native breeds. Only the Bisaro pig with below 100 sows is seen to be in critical stage but conservation program increases interest in rescue this breed as genetic resource (GAMA et al., 1997).

America's rarest swine breed, the Mulefoot pig has been formed from crossings of Berkshire and Razor Back at the beginning of this century and it is now near to extinction. The genetic analysis of the remaining herd showed gene and allele losses and uneven distribution of genotypes (KAPKE et al., 1997).

\section{Rare breeds in production}

Rare breeds are often similar in definite characters. A part of them is of early maturity, increased fatness and special muscle structure. Numerous products (e.g. Parma ham, Serrano ham and different salamis etc.) origin from those time at which they were favoured in breeding and production. In production of traditional and unique products, rare breeds may have and they still have role recently and in the future.

Italian rare breeds, as Madonie, Calabrian, Cavallino and Caserta as partners of modern breeds take place in crossings for production of raw material of the Parma ham. Similarly Hungarian Mangalica crossed with Duroc produces slaughter pigs for Spanish Serrano ham. With the same purpose the Iberian pig is commonly used in crossing with Duroc. Bazna pigs are kept by smallholders in pure and crossbred forms and their products are used at home, not for sale.

\section{Principles for conservation of native or rare breeds}

There are nowadays two main approaches for conservation of diversity of domestic pigs: preservation and utilisation. It means preservation of the breed on highest level of genetic variability and on minimum level of costs. This theory and practice in China is based on principle to avoid duplication of a special trait in more than one breed maintained (YAOSHENG et al., 1995). Genetic analysis of 47 Chinese breeds proved that $91 \%$ of distinguished traits are to be saved by conserving just 20 breeds.

Genetic resources are managed in practice by classical breeding plans based on estimation of breeding value and/or population mean values. Several methods are available for storing genes but they may be used with changing success in different species (BREM, 1989): cryopreservation (semen and embryos, cells and cell nuclei), isolated chromosomes, genomic DNA libraries, isolated genes. At the moment the majority of biotechnical methods seem to be expensive therefore they are more prospective for the future. Especially genomic DNA libraries and operations with isolated genes seem to be very useful in the near future. 
Though conservation of breeds is more or less possible by using biotechnological methods, breeders, authorities and the nations as well choose the in situ maintenance because of scientific, productional and cultural purposes. There are a lot of guidelines and directives (FAO papers: Nr. 80; 99; 104) for saving genetic variation in maintaining living breeds. As main tasks there are some important issues, such as: avoiding inbreeding, increasing effective population size and using proper mating program ensuring survival for each genotype and give equal chance to have the same number of progenies. In any cases, the program of maintenance has to go out from the actual genetic make up of the population. To get a reliable genetic map from a breed or a variety, it supposes a lot of considerations concerning genetic parameters and characters.

In recent years some papers have been published attempting to interpret and explain the long term change of genetic variation. BÜNGER et al. (1993) selecting for a growth trait or litter size in mouse found that there is only a very low or diminished selection response in range of 70 or over 80 generations that might be caused by the decreasing genetic variation.

Mating procedure can seriously influence forming genetic variance as well. Modelling of different mating systems based on data of mouse experiments and one locus model with 80 alleles, DIETL and LANGHAMMER (1997) found that a simulated mating plan for minimal rate of inbreeding may minimise reduction in available alleles and keep on low level of inbreeding coefficient. Random or phenotypic mating principles have similar inbreeding rate by higher loss in alleles after 15 generations. One quantitative trait included into mating aspects increases 3 times the inbreeding (Table 2. in: DIETL and LANGHAMMER, 1997). So, genetic diversity in a specific trait may be maintained with combining analysis of other methods.

Table 2

Differences in marker allele distributions generation 13 vs. generation 0 (BROCKMANN and LANGHAMMER, 1996) (Unterschiede der Allelverteilung von Markergenen in der 13. gegenüber der 0. Generation)

\begin{tabular}{lccccc}
\hline marker & alleles & $\begin{array}{c}\text { minimal rate of inbreeding } \\
\text { (min. inbreeding) }\end{array}$ & $\begin{array}{c}\text { basic population conversation } \\
\text { (phenotype conv.) }\end{array}$ \\
\hline D11Mit236 & 5 & s & $(-2)$ & s & $(-2)$ \\
D11Mit36 & 4 & ns & $(-1)$ & s & \\
D11Mit213 & 4 & ns & s & \\
D11Mit125 & 4 & s & s & s & $(-1)$ \\
D11Mit126 & 3 & ns & s & \\
D11Mit180 & 3 & ns & s & $(-3)$ \\
D11Mit214 & 6 & s & & & \\
\hline
\end{tabular}

Nowadays literature and practice emphasis mainly biotechnological methods as means of maintenance of rare breeds. Poor attention is given to others, as immunogenetic studies, linked markers, analysis of occurrence and distribution of different protein systems. Such measurements with known inheritance give rather useful information at the start of conservation program or later, at controlling genetic changes (FÉSÜS, 1994). SARAC et al. (1997) used these methods fi. for estimation of genetic differ- 
ences between Mangalica and Morava breeds. The study proved significant differences in distribution of some allelic genes, particularly for 6 PGD and PO2 loci between the breeds.

Blood groups, serum allotypes, serum proteins and enzyme polymorphism has been used for 15 years as markers for estimation of changes in selection trials and controlling genetic distances (OISHI and ABE, 1983; OISHI et al. 1990) or scanning of pig genome (ROHRER et al., 1997).

Examinations with blood groups and biochemical polymorphism in native pig breeds of Bangladesh helped to clear that in a lot of factors they are markedly different from other Southeast Asian native breeds but in genetic variation they are similar (KUROSAVA et al., 1987).

Conservation and preservation of the native gene reserve breeds is an important task in Hungary, as well. The work of breeders responsible for the maintenance of these populations is supported to a great extent by the immunogenetic and biochemical genetic work. The gene frequency values in the various polymorphic systems are determined and the changes are followed in each population during generations and years. Special attention is paid to the prevention of gene losses (FÉSÜS, 1994).

An analysis on genetic structure of Zlotnicka White and Zlotnicka Spotted in Poland showed that several alleles are present only in Zlotnicka Spotted and frequencies of other alleles are significantly higher than in commercial breeds. Numerous alleles being present earlier in Spotted pig were not found recently in the Zlotnicka White (KURYL et al., 1997). In a study with over sixty genetic markers in three commercial breeds and in Zlotnicka White JANIK et al. (1998) found that Zlotnicka is monomorphic for blood group B and serum protein Tf and $\mathrm{Cp}$ systems. Numerous serum proteins and lipoprotein allotypes were absent in the Zlotnicka breed showing lower level of genetic diversity.

An other problem in maintaining a rare breed is how to identify whether an individual or a group belongs to the breed or not. Out of colour or some exterior traits usually there are not available breed-specific genetic markers with which a given pig or a smaller group could be ordered to a breed. On the other hand it is fully obvious that individuals and subgroups of a breed, supposing common origin, can be identified only by using a lot of markers and by analysing their distribution. The ratio of different and common allelic variants and analysis of them by multivariate statistical methods may clear the genetic distance among populations.

A general issue is that how many genetic markers, biochemical traits should be introduced into an analysis to estimate the degree of relationship. Obviously, as many as possible. Considering that from day to day more and more genetic markers are published and involving of traits is nowadays only a financial question, it is the task to extend the examination for all possible characteristics. In contrary of the possibilities, a lot of examinations are based on the genetic determination of breeds using rather few genetic-biochemical parameters.

It remains always a question, how many traits should be analysed for conservation of a breed. Theoretically: as many as are necessary and characteristic for a breed, practi- 
cally: as many as may be realised for real costs. At the moment production traits are controlled generally in central test, sometimes in field test. Some rare breeds are selected for higher production ability in contrary with purposes of their conservation. It is easy to admit that estimation of genetic variance at the starting point of maintenance of a breed needs a wide range of genetic and phenotypic measurements involving conventional test results, exterior characteristics, biochemical and genetic markers. Without detailed detection of the actual genetic stage it is questionable to get a reliable picture of inheritance in the next generations. Recommended steps in this process are as follows:

- detailed revealing of genetic make up of the population,

- evaluation of distribution of traits,

- selection of most typical characteristics,

- selection and mating of individuals being most characteristic for the breed,

- checking each generation,

- modifying selection to save genetic feature.

\section{Conclusions}

A lot of other important recommendations and advises are described in the special literature and are already used in practice. Considering the general development of laboratory technique and results in genetics, more hundreds selected parameters seem to be sufficient to establish a relative good starting situation in maintaining a breed endangered or being in critical status. The control of genetic make up depends not only on the number of traits and parameters but also on their distribution on chromosomes. There are a lot of known loci on definite chromosomes and numerous chromosomes without detected loci or genetic markers. Therefore maintenance of a breed in original gene-composition should be based on a rather wide genetic control introducing all the chromosomes into evaluation. New results in detection of genomic markers should be continuously introduced and utilised in the preservation of rare pig breeds.

\section{References}

Animal genetic resources. ARK.

A global programme for sustainable developments (1989), FAO Paper 80, ed.: Wiener, G.

1992, The bad news and good news for rare breed pigs. 20,41-48, 1993

BACHIVANGI S.; STANCIU, M.:

The Bazna pig - the morphological and productive characteristics of identified phenotypes in Sibiu county. Inaugural Meeting of the Danubian countries alliance for conservation in animal species. BODó, I.: Budapest, Hungary, 26-28 May, 1998

Methods and experiences with in situ preservation of farms animals. in: Animal genetic resources. A global programme for sustainable development. Proceedings of an FAO Expert Consultation, (ed. Gerald Wiener) Rome, Italy, September, paper 80, 85-101, 1990

BODÓ, I.; BUVANENDRAN, V.; HODGES, J.:

Manual for training courses on the animal genetic resources conservation and management (ed. I. Bodó, V. Buvanendran and J. Hodges). FAO, UNEP, Univ. of. Vet. Sci., Budapest. 1st vol., p. 68; and vol. n 264,1984 
BREM, G.:

Future biotechnological possibilities in preserving animal germplasm. Animal Genetic resources. A global programme for sustainable development. Proceedings of an FAO Expert Consultation, Ed. Gerald Wiener, Rome, Italy, September, Paper 80. 59-67, 1989

BÜNGER, L.; DIETL, G.; RENNE, U.:

Long-term selection for body weight and fertility in mice with special consideration of a selection limit CAPUT, P.: and it's causes. 44th EAAP, Denmark, Aarhus, 16-19 August, 1-14 p., 1993

DIETL, G.; LANGHAMMER, M.:

Conservation of rare breeds of animals - objectives and possibilities. Arch. Tierz., Dummerstorf 40

FAO: (1997) Sonderheft, 135-141

FÉSÜS, L.

The management of global animal genetic resources. Proc. of an FAO Expert Consultation, Rome, Italy, April. Ed.: JOHN HODGES. Paper 104, 1992

Hungarian Research on Immunogenetics and Biochemical Genetics. Hungarian Agricultural Research, Vol. 3. No. 2. 10-14. 1994

GAMA, L.T.; MATOS, C.P.; MATASSINO, D. (ed.); BOYAZOGLU, J. (ed.); CAPPUCCIO, A.:

Current situation of animal genetic resources in Portugal. International symposium on Mediterranean animal germplasm and future human challenges. A joint EAAP-FAO-CIHEAM International Symposium. 73-76, 1997

GRUNENFELDER, H.P.:

Saving the Turopolje pig: an international pilot project in Croatia. Diversity. 9-10. 4:1. 10-11, 1994

GRUNENFELDER, H.P.; GUGIC, G.; PUNZ, F.:

Saving the Turopolje pig in Croatia. Animal Genetic Resources Information. No. 14, 27-32. 1995

In situ conservation of livestock and poultry (1992). Ed.: Henson, E.L. Paper 99.

JANIK, A.; KAMYCZEK, M.; KURYL, J.:

Genetic markers polymorphism in 4 Polish pig breeds. Paper on ISAG PIG WORKSHOP, The Netherlands, October 15-16, 1998

KAPKE, P.; JORGENSEN, H.P.; ROTHSCHILD, M.F.:

Unique collaborative conservation effort scores a win for America's rarest swine breed. Diversity. 13:1, 24-25, 1997

KUROSAWA, Y.; AMANO, T.; OKADA, I.; OTA, K.; NAMIKAWA, T.; MAEDA, Y.; HASNATH, M.A.; MOSTAFA, K.G.; FARUQUE, M.O.; MAJID, M.A.:

Blood groups and biochemical polymorphisms in the native pig populations of Bangladesh. Genetic studies on breed differentiation of native domestic animals in Bangladesh. Univ. Hiroshima, 26. Ref. 59-74. Japan, 1987

KURYL, J.; JANIK, A.; KAMYCZEK, M.; BUCZYNSKI, J.T.:

Genetic structure of Zlotnicka White and Zlotnicka Spotted pig as defined on the basis of the polymorphism of blood groups, serumproteins and lipoprotein allotype - a review. Animal Science Papers and Reports. Polish Academy of Sciences, Institute of Genetics and Animal Breeding, Jastrzebiec. 15: 3, 163-171, 1997

MAIJALA, K.; CHEREKAEV, A.V.; DEVILLARD, J. M.; REKLEWSKI, Z.; ROGNONI, G.; SIMON, D.L.; STEANE, D.:

Conservation of animal genetic resources in Europe. Final report of the European Association of MASON, I.L.: Animal Production Working Party. Livestock Prod. Sci., Amsterdam 11 (1984), 3-22

A World Dictionary of Livestock Breeds Types and Varieties. CAB International, 348 pp., 1988

OISHI, T.; HYODO, I.; JIMBO, M.; MIKAMI, H.; NISHIDA, A.: Genetic characters of three Landrace pig strins investigated by blood groups and biochemical polymorphism. Japanese Journal of Swine Sci. 27 (1990) 1, 41-47

OISHI, T.; ABE, T.:

Studies on blood groups and blood protein polymorphism as genetic markers in pigs. Proceedings, The Fifth World Conference on Animal Production. Vol. 2. Free Communications 77-78. 6. Ref. Tokyo, Japan, 1983 
RODRIGANEZ, J.; SILIO, L.; RILLO, S.M.:

El cerdo iberico y su sistema de produccion. Animal Genetic Resources Information. No. 12, 93-103, 1993

ROHRER, G.A.; VOGELI, P.; STRANZINGER, G.; ALEXANDER, L.J.; BEATTIE, C.W.:

Mapping 28 erythrocyte antigen, plasma protein and enzyme polymorphism using an efficient genomic SALEHAR, A.: scan of the porcine genome. Animal Genetics. 28 (1997) 5, 323-330

The Krskopolje pig. Pig News and Information, 15 (1994) 2, 59-61

SARAC, M.; JOVANOVIC, S.; GAGRCIN, M.:

Distribution of the allele frequencies for some polymorphic enzyme and protein systems in two Yugoslavia autochtonal pig breeds, Moravka and Mangulica. Inaugural Meeting of the Danubian countries alliance for conservation in animal species. Budapest, Hungary, 26-28 May 1992. The bad news and good news for rare breed pigs. CAB Abstracts, 1993-1994. Ark. 1993. 20. 41-48. 1998, The management of global animal genetic resources. Proceedings of an FAO Expert Consultation, Rome, Italy, April 1992. Ed.: John Hodges. Paper 104

UREMOVIC, M.:

The Black Slavonian breed of pigs is disappearing. Agronomski Glasnik. 57. 4-5, 311-316, 1995

WALKIEWICZ, A.; KONDRACKI, S.; KAMYK. P.:

Changes in population size and performance of the indigenous Pulawska pig in the years 1988-1996. Animal Science Papers and Reports, Polish Academy of Sciences, Institute of Genetics and Animal Breeding Jastrzebiec, 15: 3, 155-161, 1997

YAOSHENG, C.; LAI, M.; ZHILIAN, S.; SMITH, C.; GAVORA, J.S.; BENKEL, B.; CHESNIAS, J.; FAIRFULL, W.; GIBSON, J.P.; KENNEDY, B.W.; BURNSIDE, E.B.:

Systematic conservation theory and its application for conservation of Chinese indigenous pig breeds. Proceedings of the 5th World Congress on Genetics applied to Livestock Production, University of Guelph, Guelph, Ontario, Canada, 7-12 August, 1994. 560-563, 1995

Received: 13.11.1998

Accepted: 02.12.1998

\author{
Authors' address \\ Dr. MIHÁLY WITTMANN, PhD., Prof. Dr. Dr. h.c. mult. JÁNOS DOHY \\ University of Agricultural Sciences \\ Institute of Animal Husbandry \\ H-2103 Gödöllõ \\ Hungary
}

